European journal of American studies

Special Issue: Truth or Post-Truth? Philosophy, American Studies, and Current Perspectives in

Pragmatism and Hermeneutics

What Dewey Knew. The Public as Problem, Practice, and Art

Laura Bieger

OpenEdition

Journals

Electronic version

URL: https://journals.openedition.org/ejas/15646

DOI: 10.4000/ejas.15646

ISSN: 1991-9336

Publisher

European Association for American Studies

Electronic reference

Laura Bieger, "What Dewey Knew. The Public as Problem, Practice, and Art", European journal of

American studies [Online], 15-1 | 2020, Online since 11 May 2020, connection on 08 July 2021. URL:

http://journals.openedition.org/ejas/15646 ; DOI: https://doi.org/10.4000/ejas. 15646

This text was automatically generated on 8 July 2021.

Creative Commons License 


\title{
What Dewey Knew. The Public as Problem, Practice, and Art
}

\author{
Laura Bieger
}

Nothing so sharpens one's appreciation for democracy than bearing witness to its demolition.

Jill Lepore

1 In the face of the Brexit referendum and the Trump election, the 2016 Word of the Year Award was bad news for democracy lovers. Its winner, "post-truth"-defined as "relating to or denoting circumstances in which objective facts are less influential in shaping public opinion than appeal to emotion and personal belief"- crystallized the fragility of participatory politics in the failure of the public to act as public. ${ }^{1}$ Scholarship on the public has grappled with the question if and how publics can act as long as the idea of the public as a political actor exists. And if the term most often coupled with "post-truth" is "politics" it is important to bear in mind that a particular aspect of democratic politics (or the failure thereof) was responsible for the skyrocketing use of the term and its Word of the Year selection. "Post-truth politics" are participatory politics gone bad; politics in which the collective (and mass-mediated) practice of deliberation through which democratic publics exist has succumbed to the emotional mobilization of charismatic spin doctors, be they democratically elected politicians or self-appointed (social) media pundits.

2 So yes, the present situation reminds us that the concept and practice of deliberation, which is key to the project of participatory democracy, both appeals to and relies on a collective process of establishing common ground in the form of "shared truths." And if "post-truth politics" strategically aligns itself with philosophical traditions such as pragmatism and postmodernism and their claims that truth is socially constructed rather than metaphysically imposed, it is our job as scholars to make clear that the present "post-truth" threat to democracy (and the populist appeal of the term itself) lies not in a relativist, anti-foundational understanding of truth. The threat of "posttruth politics" lies in its politically motivated assault on democratic procedure. It lies, in other words, in exploiting the emotional and the personal (which happen to be the main currencies of interaction and engagement in the world of social media) to 
suspend, and possibly destroy, the protocols of social interaction and engagement on which participatory politics relies in its need to establish common ground in a continuous process of defining "things public" (or res publics). Such "things" are valued not out of "personal" or "special interest," but out of "common interest." But what 'common interests' are is hardly obvious. Defining them takes deliberation-the careful and extended, discussion-based consideration of options, which intersects and interacts with other political practices, such as decision making, jurisdiction, and voting. ${ }^{2}$

3 As this collective, reflective practice, deliberation-in the circular motion that is a staple of all performative acts-brings forth both the actor (the public) and object of its engagement (res publica). The public is a political actor that knows (and constitutes) itself by knowing (and defining) its interests. Which also means that debates about what the public is and does, how it can articulate itself and act, are-in their peculiar, self-reflective circularity-a driving force in the deliberative process that is the root of democratic politics. This essay takes the present "post truth" threat to democratic politics as an occasion to revisit John Dewey's view of the public as a political actor that is both indispensible for the project of modern democracy and vulnerable to selfeffacement. Part of what makes this exercise so enticing is Dewey's ambition to have an impact in this debate. The Public and Its Problems (1927) is Dewey's most substantial work of political philosophy, for sure. But its immediate goal was to remedy the public's capacity for political action. In writing and publishing this book, Dewey sought to restore faith in democratic politics and procedures at a time when fascism and totalitarianism were one the rise (and a new social medium, the radio, emerged). And if this goal has renewed relevance today Dewey's view of the public is all the more instructive since it is grounded in concerns about what counts as truth and how the public is involved in determining it. The opening lines of The Public and Its Problems could indeed very well be an intervention in current debates about the intertwined states (or fates) of truth and democracy:

If one wishes to realize the distance which may lie between 'facts' and the meaning of facts, let one go to the field of social discussion. Many persons seem to suppose that facts carry their meaning along with themselves on their face. Accumulate enough of them, and their interpretation stares at you. The development of physical science is thought to confirm the idea. But the power of physical facts to coerce belief does not reside in bare phenomena. It proceeds from method, from the technique of research and calculation.... Take away from physical science its laboratory apparatus and its mathematical technique, and the human imagination might run wild in its theories of interpretation even if we suppose the brute facts to remain the same. (3)

4 The realm of science is a remarkable point of departure in Dewey's "search of the public" (3). This choice is programmatic insofar as it allows him to establish from the get-go that even in the realm of science, knowledge and truth are products of interpretation. Dewey firmly believes that science has no privileged access to knowledge whatsoever; like all other attempts at knowing the world, it seeks to understand the meaning of a certain phenomenon in a given context. And just like all other attempts at knowing the world, science is guided by the concepts and goals that humans-as thinking and judging beings-bring to the problem at hand. Which means that selection and judgment are at work in any effort of knowing the world. Knowledge itself is bound up with the concrete conditions of human life, in which one sample or piece of information is chosen over another based on certain evaluative criteria. 
"Knowledge is a function of association and communication; it depends upon tradition, upon tools and methods socially transmitted, developed and sanctioned," he writes (158). Which leads him to conclude that our attempts at knowing the world result in opinion rather than truth; and that, if not even science can deliver "the truth" (and not even facts have irrefutable meaning), the production of knowledge should be the business of a scientific community operating on the basis of democratic principles such as free speech, rational deliberation, and intersubjective exchange (Kloppenberg 50-54; see also Dewey, Experience and Nature; "The Reflex Arc Concept in Psychology").

So, for Dewey, in the absence of absolute truth, a dialogically tested and gauged kind of knowledge is the best we can get. Moreover, for Dewey (as for Peirce, from whom he takes the idea), the scientific community is a laboratory of collective, intersubjective reasoning, and modern democracy is its social equivalent. In democratic as well as in scientific communities, free and creative individuals conjointly engage in formulating and testing hypotheses to find out what works best to solve concrete and practical problems. For Dewey, any dissonance or disjunction between these two groups only shows that they are not yet living up to the purpose for which they exist-to serve public interest in a democratic society. ${ }^{3}$

The epistemic dimension of Dewey's political philosophy that becomes tangible here has recently contributed to a new development in democratic theory, which seeks to establish "the value of democracy on the basis of epistemic merits expected to accrue from certain democratic procedures" (Estlund 261). Scholars aligning their work with this idea assume that democracies are inclined to make good decisions because the decision-making process is grounded in an inclusive and dialogic mode of knowledge production. "Epistemic democrats have developed a cluster of arguments to the effect that the wisdom of the many can be mobilized by democratic arrangements and that this provides an important defense of democracy" (Festenstein 218). My discussion of Dewey's views of the public as a political actor is inspired by this line of work, especially by those of its protagonists (among them James Kloppenburg, Hilary and Ruth Anna Putnam, Elizabeth Anderson, and Matthew Festenstein) who turn to Dewey to "support a view of democracy as a collective exercise in practical intelligence" (Festenstein 219-20; here 219). But it also seeks to point beyond established understandings of epistemic democracy in connecting this line of work with Dewey's view of communication as art to argue that the aesthetic is assigned with a crucial role in collectively exercising the practical intelligence that both sustains democracy and pushes it forward-and that epistemic democrats have overlooked so far.

7 Any discussion of Dewey's political philosophy must grapple with his expansive understanding of democracy. Democracy is, for Dewey, "a tendency built into the very structure of social activity" (Bybee 49). Dewey developed this "idea of democracy in its generic social sense" (The Public 147) over the course of his long career. In The Public and Its Problems, he explains it as follows:

From the standpoint of the individual, it consists in having a responsible share according to capacity in forming and directing the activities of the groups to which one belongs and in participating according to need in the values which the groups sustain. From the standpoint of the groups, it demands liberation of the potentialities of members of a group in harmony with the interests and goods which are common. Since every individual is a member of many groups, this specification cannot be fulfilled except when different groups interact flexibly and fully in connection with other groups.... There is a free give-and-take: fullness of 
integrated personality is therefore possible of achievement, since the pulls and responses of different groups reinforce one another and their values accord. (147) ive the optimism that is surfacing here (as he did himself in "Creative Democracy," a late-career meta-reflection on the topic at hand). Dewey's unwavering faith in the possibilities of democracy in the modern age was an antidote to feelings of doubt that were all too common in his time ${ }^{5}$-and in the U.S. context perhaps most powerfully expressed by Walter Lippmann (in a number of publications, including his two books Public Opinion and The Phantom Public). It is well known that Dewey wrote The Public and Its Problems in response to Lippmann's laconic dismissal of the public as a phantom. ${ }^{6}$ But while Dewey's and Lippmann's views of the public and its significance for the project of modern democracy could not have been more different, it is worth noting that both turned to the public in a way of grappling with the growing despair about the future of democracy that marked their time. The experience of the Great War had eroded peoples' faith in the fundamentally rational nature of humankind, and in the aftermath of the war, attempts to secure a lasting peace built on Wilson's Four Freedoms had been futile, efforts to establish democratic governments in Germany and Italy were thwarted, and the Bolshevik revolution was challenging the social ideals of Western democracies. U.S. democracy, too, was not in a good shape in the thirties, "weakened by corruption, monopoly capitalism, apathy, inequality, political violence, hucksterism, racial injustice, unemployment, even starvation" (Lepore 20).

Against this backdrop of geopolitical turmoil and shattered beliefs, Lippmann and Dewey formulated their opposing views on the public and its role in modern democracies. Lippmann, who had severe doubts about the capacity of the average citizen to engage in rational self-government, advocated a positivistic science to renew the project of modern democracy (-and the fact that Dewey uses the realm of science to embark on his "search for the public" is a direct response to this view). Given the tendency of individuals to distort what they see (a point that Lippmann had elaborated in Public Opinion), participation of the average citizen in democratic procedures was best to be minimized. In fact, for Lippmann, democratic governance could only be salvaged by grounding it in a kind of knowledge that rises above subjectivity and politics: scientific knowledge. "The Pandora's box of the relativity of truth," opened by scientists such as Einstein and Heisenberg, "would be carefully resealed, and line drawn... between fact and fiction" (Bybee 32)-with such things as "the public" or "the people" falling on the latter side. Note how the pattern repeats itself today, as the relativism of postmodernism has come to serve as the scapegoat for the current problems of democracy.

11 For Dewey, democracy could not be saved by science (or at least not by science alone) because science had its own problems. Was it indeed not greatly ironic that science, 
once it had shattered metaphysical truth, claimed for itself a truth that existed outside of the influence or control of human doing and making? Again, the parallels to critical paradigms such as new materialism/positivism, which are en vogue even in the humanities today, are striking. And if a precursor of this quarrel set the stage for Dewey's book on the public, his point about this kind of science (which he elaborates most consistently in The Quest of (ertainty) is still valid today: a positivistic science can neither solve the problems of subjectivity nor those of democracy. It "avoids them or worse, hides them" (Bybee 32).

And while Dewey largely agreed with Lippmann's diagnosis of the troubled state of modern democracy-it suffered from the bureaucratization and impersonalization of modern life and from the growing power of economic forces to secure interests in government-he believed, contrary to Lippmann, that these problems could not be solved by establishing an intellectual elite that pretended to have access to a truth untainted by human interests. For Dewey, the only remedy was to revive the public, which was "eclipsed" (121) rather than being a phantom. So, while Lippmann's goal was to save the project of modern democracy by exposing the public as a chimaera, reduce participation to a bare minimum, and install a technocratic mode of governance, Dewey wanted to reach the same goal by reanimating the public in a step toward reviving democracy in its encompassing social sense. Against assumptions of "the epistemic superiority of an expert class" (Festenstein 224), Dewey argued that "in the absence of an articulate voice on the part of the masses, the best do not and cannot remain the best, the wise cease to be wise.... In the degree to which they become a specialized class, they are shut off from knowledge of the needs which they are supposed to serve" (The Public 206). And if an open and inclusive debate yields epistemically better results, the expert class must "bind itself to these processes" (Festenstein 224). For Dewey, democracy, in institutionalizing "effective guarantees of free inquiry, free assembly and free communication" ("Creative Democracy," qdt. in Festenstein 224), creates the best conditions for this.

13 How good these conditions are depends to a substantial degree on the public's capacity to act as public. For Dewey, this capacity is rooted in a process of collective reflection grounded in shared experience and communication. And by the latter, Dewey "did not mean the machinery of communication" that interlinks science, the press, and the political system, "but the art of communication, the process by which citizens in a society came to understand the nature of their interdependence through a system of shared meaning" (or "truths") (Bybee 32). ${ }^{7}$ For Dewey, the public is essential in cultivating this art and making political use of it. I will pursue this line of thought further later on, but first, I want to turn to Jürgen Habermas, whose work on the public has shaped my understanding of the subject at hand before I read Dewey. Habermas's Strukturwandel der Öffentlichkeit (1964), published in English much later as Transformations of the Public Sphere (1989), was formative for my view of the public as a political agent that acts (and knows itself) through mass-mediated communication, and as a literary scholar I was (and still am) intrigued by the lucidity and consequence with which he grounds the public's capacity for political action in reading (and) literature. But I also agree with his critics that, for understanding the heterogeneous, pluralist, and conflicted nature of the public as a staple of modern democracies, the Habermasian model is limited and ultimately limiting (see specially Fraser; Warner, Publics; Squires.) And yet, reading Habermas in tandem with Dewey makes both the merits and the 
limitations of Habermas's influential model of the public as a political actor especially tangible. But to my knowledge, this is rarely done.

In my attempt to start filling this gap, I want to open with the thrust of the Habermasian model of the public as a political actor: the assumption that printing technology brought into the world new forms of publicness, which prompted new forms of politics. ${ }^{8}$ Habermas traces the shift from a pre-modern, "representative publicness," mediated through visible signs of status and power and residing in their public display, to a modern, discursive publicness, mediated through print discourse and residing in a shared use of texts in Transformations of the Public Sphere (5-26; see also Warner, "Publics" 62-68). The story that unfolds from here is by now a familiar one. With its appeal to reason and objectivity, its spirit of collective evaluation and debate, and its capacity to invoke a sense of connectedness among readers who were strangers to each other, the discursive publicness of print was key to generating "the political structures of modernity" (Warner, Letters xi). It was indeed print-based publicness that tied communicative exchange and deliberation to political institutions and practices in ways that turned them into political practices in their own right. We find a kernel of this thought in The Public and Its Problems, where Dewey writes: "a thing is only fully known when it is published, shared, socially accessible. Record and communication are indispensible to knowledge" (178). But it was Habermas who first gave systematic thought to how print-based publicness became a "training ground" (Public Sphere 29) for the political practice of deliberation.

For Habermas, the public emerges as a political actor when private people start making use of their reason in public. This was possible because in modern societies, the private, intimate realm of the domestic sphere had become the site at which a new, audienceoriented mode of subjectivity was being forged; a mode of subjectivity trained by reading sentimental novels and writing letters and diaries, which turned out to be highly compatible and indeed very well suited to perform in the "coffee houses, salons and Tischgesellschaften" (51) that were formative sites of the literary public sphere. The political agency emerging from these sites was grounded in an imagined web of "intimate mutual relationships between privatized individuals," authors and readers weeping over the fate of invented actors, who, in doing so, "themselves [became] actors who 'talked heart to heart"' (50). Note how the practice of deliberation rehearsed under these conditions was not cool or withdrawn but emotionally engaged. We are touching on a neuralgic point of the public's political agency here: how to reconcile the need for rational and emotional mobilization at work in summoning a public into existence. Both are needed, yet any theory that assigns the public with a capacity for political agency must attest human beings with the capacity to be rational. But what does it mean (or take) to be rational? For the Habermas of Transformations of the Public Sphere, reason is grounded in communicative exchange and sentimental education. And while the latter recedes into the background in his subsequent work, the idea that democratic reason (and collective intelligence) is fostered in free communication becomes the backbone of Habermas's theory of communicative action, where reason is universalized as an potentially progressive propensity that, due to natural yet noncoercive tendencies inherent in human communication, prompts humankind to collaborate (Habermas, Theorie des Kommunikativen Handelns; see also Kloppenberg 74-75). 

(especially in Democracy and Education and Experience and Nature). "Long before Habermas published his magnum opus on communicative action, Dewey concluded that humanity had yet to understand the significance of, and the potential benefits that could be generated, by socializing and systematizing democratic communication" (Dotts 114; see also Kloppenberg 74-76). In The Public and Its Problems, Dewey states: "Knowledge," i.e. the product of using one's reason, "is a function of association and communication; it depends upon tradition, upon tools and methods socially transmitted, developed and sanctioned" (158). Or: "No man or no mind was ever emancipated merely by being left alone" (168). And later (in "Democracy and Educational Administration") he writes:

The foundation of democracy is faith in the capacities of human nature; faith in human intelligence, and in the power of pooled and cooperative experience. It is not belief that these things are complete but that if given a show they will grow and be able to generate progressively the knowledge and wisdom needed to guide collective action. (qtd. in Festenstein 219)

Habermas had not read Dewey when writing his habilitation on the public sphere in the early 1960s, but he later acknowledged the major influence that Dewey could have easily been (Habermas, "Postscript" 228). And it is indeed striking that both thinkers reach a similar conclusion: communication based on democratic principles assigns publics with an epistemic role. In this view, communication is not merely a transmitter of knowledge, but a proactive participant in creating a system of shared meanings (see also Bybee 55).

Both Transformations of the Public Sphere and The Public and Its Problems envision the possibilities of modern democracy that manifest themselves in the public's capacity for political action as gauged by concrete material structures and hermeneutic procedures. And quite different from the universalizing tendencies of Habermas's later works, Transformations of the Public Sphere pays close attention to the historically specific practices of reading and reading communities that sustain the public's political agency. In doing so (and this is one of the great virtues of this book), it brings literature into view as a social practice that is instrumental in forging audience-oriented subjects inclined to engage in public debate. For Habermas, the new forms of democratic politics enabled by this development crystallize in the birth of the democratic idea of rule of law:

The criteria of generality and abstractness characterizing legal norms had to have a peculiar obviousness for privatized individuals who, by communicating with each other in the public sphere of the world of letters, confirmed each other's subjectivity as it emerged from their spheres of intimacy. For as a public they were already under the implicit law of the parity of all cultivated persons, whose abstract universality afforded the sole guarantee that the individuals subsumed under it in an equally abstract fashion, as 'common human beings,' were set free in their subjectivity precisely by this parity. (Public Sphere 54)

So yes, for Habermas the discursive publicness afforded by print was essential to bringing forth the public as a political actor and to institutionalizing deliberation as the political practice that sustains its existence and agency. And yet, he seems to assume that this agency can best be asserted in communicative situations-i.e. the aforementioned "coffee houses, salons and Tischgesellschaften" (51)-that allow for a presumably transparent and direct form of intersubjective exchange. And this means that the mediated activity of reading is relegated to the second tear, whereas direct 
intersubjective exchange is viewed as the most valuable form of participation. But does not his own example of how profoundly reading sentimental novels has affected the formation of an audience-oriented subjectivity contradict this assumption in showing that the face-to-face is never fully transparent? That the language we use, the forms of address we choose, the modes of deliberation available to us, the purpose and aim of our speech, that all these features of communication are deeply pervaded by our media use? This blind spot about the fundamental opacity of communication is all the more problematic as it comes in tow with a wholesale rejection of modern mass media, of which print-in advancing the commodification of culture by catering to the appetites of the (predominantly bourgeois) reading public (29)-is an early harbinger.

How does Habermas's view of the public as a political actor that both depends upon and is impaired by modern mass media compare to Dewey's? If the Habermasian model is technologically grounded (in the shift in the social fabric of modern life brought about by what Benedict Anderson has called the rise of "print capitalism"), Dewey's model is grounded in shared experience, with negative experience being the strongest incentive for shared experience. The account of how experience is shared and how this process can generate common interest and public self-awareness deserves a lengthy quotation:

Conjoint, combined, associated action is a universal trait of the behavior of things. Such actions have results. Some of the results of human collective actions are perceived, that is, they are noted in such ways that they are taken account of. Then there arise purposes, plans, measures and means to secure consequences which are liked and eliminate those which are found obnoxious. Thus perception generates a common interest; that is, those affected by the consequences are perforce concerned in conduct of all those who along with themselves share in bringing about results. Sometimes the consequences are confined to those who directly share in the transaction which produces them. In other cases they extend far beyond those engaged in producing them. Thus two kinds of interests and of measures of regulation of acts in view of consequences are generated. In the first, interest and control are limited to those directly engaged; in the second, they extend to those who do not directly share in the performance of acts. If, then, the interest constituted by their being affected by the actions in question is to have any practical influence, control over the actions which produce them must occur by some indirect means.

So far the statements, it is submitted, set forth matters of ascertainable fact. Now follows the hypothesis. Those indirectly affected for good or for evil form a group distinctive enough to deserve a name. The name selected is The Public. (The Public 34-35)

21 Note how, for Dewey, collective response to negative experience not only summons the public into being; it can move democracy forward. An "ontology of becoming" (Crick, Democracy 37) animates his universe of thought, and this ontology also shapes his view of the public. His language underscores this conviction: "When Dewey speaks of 'the public,' his words are words of process, of transformation, of undergoing. The task is to 'call a public into existence,' meaning the task is to forge a version of 'the public' able to overcome intelligently the obstacles before it" (Stob 235). Which also means: he is less interested in what the public is and more interested in what it does; which is essentially: how it orients itself toward what it can become.

Moreover, and crucially, in Dewey's progressive model, the formation of the democratic state grows out of the formation of the public. "The public is organized and made effective by means of representatives... association adds to itself political organization, and something which may be government comes into being: the public is 
a political state" (The Public 35). But at the same time, Dewey views the public as an antagonistic force: "to form itself, the public has to break existing political forms. This is hard because the forms are themselves the regular means of institutional change" (31). In contrast to Habermas, who fails to acknowledge the plural, heterogeneous and conflicted nature of the public in modern democratic societies, Dewey's public is nonunitary, diversified-oppositional by nature. Yet while the structural antagonism between publics and counter-publics is by now viewed as a staple of modern democracies, and scholarship on the subject is proliferating, the Habermasian model remains the default point of reference while Dewey's work goes largely unnoticed. ${ }^{9}$

This is all the more unfortunate since the dominance of the Habermasian model levels tensions between different traditions of thought on the subject that may help us gain a firmer grasp on how the deliberative processes that assign democratic publics with their role as political actors are sustained by different political and intellectual cultures. European thinkers from Jean-Jacques Rousseau to Jürgen Habermas tend to envision democratic publics as capable of expressing (or at least moving toward) an ideal of consensus: If those engaged in deliberation are sufficiently rational they will conjointly articulate what the public wants. The relative ease with which thinkers of this tradition subscribe to unifying ideas such as the 'public good' springs from this consensus trajectory. In contrast, U.S. thinkers from James Madison via John Dewey to Michael Warner tend to conceive of the public as genuinely fractured by rivalling interests. In this scenario, democracy must be based on a model of governance capable of containing the resulting tensions and conflicts-a procedural model that was for the first time fully expressed in Federalist Paper 10, where "Publius" a.k.a. Madison argues that an "extended republic" is better suited than a small republic to protect public interest against special interest (the interest of 'factions', in the language of the time).

In contrast to the consensus-oriented models of the public that vastly influence scholarship on the public to this day, Dewey envisions a public that moves from conflict to conflict; or rather, from experiment to experiment. Conceived as a collective response to negative experience, the public cannot cease to exist. "The public consists of all those who are affected by the indirect consequences of transactions to such an extent that it is deemed necessary to have those consequences systematically cared for" (The Public 12). But it can cease to do the things that make response to negative experience collectively felt and heard. "Recognition of evil consequences brought about a common interest which required for its maintenance measures and rules, together with the selection of certain persons as their guardians, interpreters, and, if need be, their executors" (13). The crucial term here is recognition-"recognition of itself" (77) and recognition of its common interests. "It is not that there is no public," Dewey writes, "no large body of persons having a common interest in the consequences of social transactions. There is too much public, a public too diffused and scattered and too intricate in composition. And there are too many publics" (137). Only when the public is sufficiently aware of itself and its interests can it properly function. And for Dewey, this is "primarily and essentially an intellectual problem" (126)-a problem that can be solved by means of communication in the sense of a democratic, public art mentioned above and to which I now want to return.

In assessing how Dewey envisions the realization of this art, it is crucial to bear in mind that his model of a public coming into being in response to shared experience raises the cognitive question of how individual experience becomes collective, shared experience. 
This process requires reflection, interpretation, and communication, yes. But if assigned with a political function in modern democratic societies it also requires communication technology. For Dewey, the sheer fact that negative experience creates a need to be shared forms a practical link between communication and technology. This link is a given rather than a structural hazard. And in addressing what keeps communication in his times from realizing his ideal of communication as democratic art, Dewey contends that the "physical tools of communication" (142) are not properly used. So, contrary to Habermas's view that public discourse is, from its inception, threatened by its structural dependence on modern mass media, for Dewey, a fully realized democratic art of communication must absorb the benefits of new communication technologies. "When the machine age has... perfected its machinery, it will be a means of life and not its despotic master. Democracy will come into its own, for democracy is the name for a life of free and enriching communion" (The Public 184; on Dewey and communication technology see also Richard).

Realizing the utopian potential of communication as democratic art also depends on the availability of signs and symbols to members of a given social group to convey the sense of shared experience that, according to Dewey, is foundational to defining the common interest through which a public knows itself. Next to (and in conjunction with) the improper use of the existing communication technology, Dewey deems an impoverished language responsible for the unrealized potential of the public art of communication at his time. I have discussed Dewey's argument about how signs and symbols are needed to create a robust system of shared meanings, and how "their dissemination in print" (The Public 218) is crucial to creating this system elsewhere (see my "Reading for Democracy). For the present purpose suffice it to say that, if Habermas views literature and the literary public sphere as a vital "training ground" for the audience-oriented subjectivity that lends political agency to the collective, reflective practice of deliberation, Dewey assigns literature with a key role in generating new signs and symbols for the democratic art of communication. And by using these signs and symbols in ways that transform the force of experience into collective action, "[p]oetry, the drama, the novel are proofs that the problem of presentation is not insoluble. Artists have always been the real purveyors of news, for it is not the outward happening in itself which is new but the kindling by it of emotion, perception and appreciation" (183).

So yes, similar to Habermas, Dewey assigns literature with a vital role in the constitution of the public as a political actor. ${ }^{10}$ In Habermas's technology-/mediaoriented model, literature features as a social practice that provides the scripts and infrastructure in and through which deliberation becomes a political tool. In Dewey's experience-based model, in which political agency depends on the realization of the democratic potential of communication, literature features as a distinctly aesthetic practice with a transformative capacity to move democracy forward. For Habermas, literature is both essential to the constitution of democratic publics and a driving force in its decline. It is closely involved in creating audience-oriented subjects ready to engage in political deliberation and a network of actors and spaces through which deliberation can assert political power, but it is also part of a dynamic of commodification that is bound to impair this power. Dewey's view of literature's contribution in creating a robust public is less conflicted. He trusts literature's capacities to transform social interaction through its art of communication. Yet he, too, views the face-to-face mode as the gold standard of democratic communication and 
deliberation. "Systematic and continuous inquiry into all the conditions which affect association and their dissemination in print is a precondition of the creation of a true public," he writes. "But it and its results are tools after all. Their final actuality is accomplished in face-to-face relationships by means of direct give and take" (The Public 218). But if Dewey's view on the public's capacity for political action also lacks an awareness of the fundamental opacity and mediatedness of the face-to-face, his vision of democratic communication is open to accommodating communication technology. In fact, for Dewey, the utopian state of perfect communication that lets public discourse flow freely demands that communication technology is subsumed in a community's democratic intentions.

To conclude: my reading of Dewey's The Public and Its Problems in tandem with Habermas and in resonance with current efforts to provide an epistemic justification of democracy opens three trajectories for future scholarship on the public and its capacities for political action. Scholars interested in the structural tensions and antagonisms that mark modern democratic publics may gain a firmer grasp on the matter by juxtaposing conflict/experiment and consensus models of deliberation and by placing these models in their respective critical and political traditions. Scholars interested in Dewey's vision of "democracy as a collective exercise in practical intelligence" (Festenstein 219) may see that they need to start reckoning with the impact that communication technology has on the progressive and inclusive generation of knowledge and wisdom. And last but not least, scholars from both traditions may see that a comprehensive account of Dewey's view of the public as a political actor must engage both with the epistemic dimension of modern mass media and with the epistemic dimension-the practical knowledge-of literature. If Dewey knew that unleashing the public's capacity for political action depends on uniting communication technology and literary art it takes the work of media and literary scholars to spell out these implications today.

\section{BIBLIOGRAPHY}

Asen, Robert. “The Multiple Mr. Dewey: Multiple Publics and Permeable Borders in John Dewey's Theory of the Public Sphere." Argumentation and Advocacy, vol. 39, no. 3, 2003, pp. 174-188.

Bieger, Laura. "Learning from Hannah Arendt; or, the Public Sphere as a Space of Appearance and the Fundamental Opacity of the Face-to-Face." American Counter/Publics, edited by Ulla Haselstein, Frank Kelleter, Alexander Starre and Birte Wege, Winter, 2019, pp. 37-52.

----. "Reading for Democracy." Democratic Cultures and Populist Imaginaries, edited by Donald E. Pease, REAL Yearbook of Research in English and American Literature, vol. 34, 2018, pp. 203-219.

Bybee, Carl. "Can Democracy Survive in the Post-Factual Age?" Journalism and Communication Monographs, vol. 1, no.1, spring 1999, pp. 29-62.

Crick, Nathan. Democracy and Rhetoric: John Dewey on the Arts of Becoming. South Carolina UP, 2010. 
---. “John Dewey's Aesthetics of Communication. Southern Communication Journal, vol. 69, no. 4, 2004, pp. 303-319.

Dewey, John. The Public and Its Problems. Henry Holt and Company, 1927.

----. Experience and Nature. 1929. Dover, 1958.

----. “The Reflex Arc Concept in Psychology." Psychological Review, vol. 3, no. 4, 1896, pp. 357-370.

Dotts, Brian W. "Dewey Anticipates Habermas's Paradigm of Communication: The Critique of Individualism and the Basis for Moral Authority in Democracy and Education." Education and Culture, vol. 32, no. 1, 2016, pp. 111-129.

Estlund, David. "Epistemic Approaches to Democracy." Sage Encyclopedia of Philosophy and the Social Sciences, edited by Byron Kaldis, Thousand Oaks, 2013, pp. 261-262.

Festenstein, Matthew. “Does Dewey Have an 'epistemic argument' for Democracy?" Contemporary Pragmatism, vol. 16, no. 2-3, 2019, pp. 217-241

Fraser, Nancy. "Rethinking the Public Sphere: A Contribution to the Critique of Actually Existing Democracy." Social Text, vol. 25, no. 26, 1990, pp. 56-80.

Habermas, Jürgen. Structural Transformations of the Public Sphere: An Inquiry into a Category of Bourgeois Society. 1964. Translated by Thomas Burger, MIT P, 1989.

Kloppenberg, James T. "Demokratie und Entzauberung der Welt: Von Weber und Dewey zu Habermas und Rorty." Philosophie der Demokratie: Beiträge zum Werk von John Dewey, edited by Hans Joas, Suhrkamp, 2000.

Lepore, Jill. "In Every Dark Hour.” The New Yorker, 3 Feb. 2020, pp. 20-24.

Mattern, Mark. “John Dewey, Art and Public Life.” The Journal of Politics, vol. 61, no.1, 1999, pp. 54-75.

Richards, Daniel. "Digitizing Dewey: Blogging an Ethic of Community." Computers and Composition Online, Fall 2011. Accessed 10 Jan. 2018.

Schatzki, Theodore R. "Introduction: Practice Theory." The Practice Turn in Contemporary Theory, edited by Theodore R. Schatzki, Karin Knorr Cetina and Eike von Savigny, Routledge, 2001, pp. $1-14$.

Squires, Catherine R. "Rethinking the Black Public Sphere: An Alternative Vocabulary for Multiple Public Spheres." Communication Theory, vol. 12, no. 4, 2002, pp. 446-468.

Stob, Paul. "Kenneth Burke, John Dewey, and the Pursuit of the Public." Philosophy and Rhetoric, vol. 38, no. 3, 2005, pp. 226-247.

Stroud, Scott R. "John Dewey and the Question of Artful Communication." Philosophy \& Rhetoric, vol. 41, no. 2, 2008, pp. 153-183.

Waks, Leonard. "Literary Art and the Formation of the Great Community: John Dewey's Theory of Public Ideas in The Public and Its Problems." Education and Culture, vol. 30, no. 2, 2014, pp. 35-46.

Warner, Michael. "Publics and Counterpublics." Public Culture, vol. 14, no. 1, fall 2002, pp. 49-90.

----. The Letters of the Republic: Publication and the Public Sphere in Eighteenth Century America, Harvard UP, 1992. 


\section{NOTES}

1. www.languages.oup.com/word-of-the-year/word-of-the-year-2016. It is no coincidence that 2016 marks the year when the Democracy Index, which rates one hundred and sixty-seven countries every year, for the first time listed U.S. democracy as a 'flawed democracy'. See Lepore 21.

2. This praxeological understanding of deliberation, and by extension of the public as an actor brought forth by the practice of deliberation, draws on the work of scholars associated with the recent 'practice turn' in social theory. For a useful introduction, see Schatzki.

3. This view of the relation between the scientific community and the public draws on Kloppenberg. An early line of criticism of Dewey's political thought has seen this analogy as indicative of a reductive and technocratic view of political democracy. Recent scholarship has countered this interpretation with one that views Dewey as "a theorist of popular contention-of class struggle, strike action, social movements, industrial democracy, civil disobedience, and coercive political action." See Festenstein 220-22; here 221.

4. Estlund clarifies: "Epistemic approaches do not assume that actually existing democracies make good decisions, or even that greatly improved arrangements would lead to predominantly good decisions. What makes them count as epistemic approaches is their holding that an adequate normative theory of democracy's legitimacy, authority, or justification depends partly on some tendency of (some) democratic arrangements to make good political decisions by aiming to do so" (262).

5. Lepore reminds us in a recent essay, launching a New Yorker series on "The Future of Democracy," that town halls, radio and newspaper debates about the meaning and future of democracy were a staple of U.S. public culture in the thirties.

6. I am closely following Bybee's lucid discussion of the Lippmann-Dewey "debate" (and the first thing that Bybee points out is that "debate" is a euphemism for a one-sided response by Dewey to Lippmann's widely received view on the topic).

7. Scholarship on Dewey's view of communication as art abounds. See especially Crick, Dewey's Aesthtics; Mattern; Stroud.

8. The following passages on Habermas and Dewey rehearse and expand on arguments that I have made elsewhere. See my "Reading for Democracy" and "Learning from Hannah Arendt."

9. For a rare example, see Asen.

10. It should be mentioned that, in The Public and Its Problems, this role is assigned but not explicated. Dewey fleshes it out in other writings, especially in Democracy and Education. For an indepth discussion, see Waks.

\section{ABSTRACTS}

This essay takes the present "post truth" threat to democratic politics as an occasion to revisit John Dewey's view of the public as a political actor that is both indispensible for the project of modern democracy and vulnerable to self-effacement. Drawing on a recent development in democratic theory-epistemic democracy-that is in part inspired by Dewey, I trace how Dewey's relativist understanding of truth animates his views of the public as a political actor and of democracy as a "collective exercise in practical intelligence" (Festenstein). But in linking the 
epistemic thrust of Dewey's political theory with his view of communication as art, I move beyond established understandings of epistemic democracy to argue that the aesthetic is assigned with a key role in collectively exercising the practical intelligence that both sustains democracy and moves it forward-and that epistemic democrats have overlooked so far.

\section{INDEX}

Keywords: the public; epistemic democracy; communication; aesthetics; John Dewey; Jürgen Habermas

\section{AUTHOR}

\section{LAURA BIEGER}

Laura Bieger is Professor of American Studies, Political Theory and Culture at the University of Groningen, where she co-directs the Research Center for Democratic Culture and Politics. She is the author of Belonging and Narrative (2018), which considers the need to belong as a driving force of literary production and the novel as a primary place and home-making agent. In another book, Ästhetik der Immersion (2007), she examines public spaces from Washington DC to the Las Vegas Strip that turn world-image-relations into immersive spectacles. Her essays have appeared in New Literary History, Narrative, Studies in American Naturalism, Amerikastudien/American Studies and ZAA. Her current research explores "reading publics" as a democratic institution and "engaged literature" as a tool for social change. 